\title{
Implementation Business Licensing Regulations Law Based Risk in the Act of Cipta OSS in Working through the Indonesia Country System
}

\author{
Desty Anggie Mustika ${ }^{1}$, Riswadi $^{2}$ \\ \{desty@uika-bogor.ac.id ${ }^{1}$, riswadi@borobudur.ac.id ${ }^{2}$ \} \\ Universitas Borobudor, Jakarta, Indonesia ${ }^{1,2}$
}

\begin{abstract}
Implementation permission-based risk by system OSS. But at the time management permission with OSS -based risk, one of the KBLI contained in SE 18/2021 cannot be processed. Indeed, not all KBLIs have been tested, but one of the 353 KBLIs has been processed can't return NIB and yet no monitor. If capital works in OSS following the money working regulated in the PT Law, the capital is working according to the authorised capital and what happens to the issued and paid-up capital. The concern is that the is PT Law understood differently. Article 103 stipulates: Affirmation suitability activity use the land for commercial activities conducted through the OSS; therefore, the investigation on the implementation of risk-based commercial clearance by Act Implementation Work Recruitment is necessary to understand the latest updates for business actors. The method used is a qualitative descriptive method that aims to apply legislative techniques active and content analysis in the research literature to understand the concepts different of the process research. The method used is qualitative descriptive yang trying to understand the various concepts found in the research process, using the content analysis technique, regulations, and favourable legal and literature. Government Regulation No. 24 of 2018 regulates licensing business integrated electronically or single online filing (OSS). System It still encounters some obstacles in its implementation.
\end{abstract}

Keywords: Government Regulation; Risk Regulation; Descriptive Method; System OSS

\section{Introduction}

Indonesia is a country that believes in the rule of law and recognises the need for integrity, professionalism and responsibility in upholding the rule of law. For this reason, the newly created legal system must also function effectively to capture and answer all legal problems that arise in the community. According to Lawrence Friedman, good law must answer unresolved issues in the legal system, divided into three (three) categories: legal structure, legal substance, and legal practice. Therefore, everything done in the national legal system must be adapted to the conditions and goals of the country [1]. 
In the context of the Indonesian state, this can be done by adapting the values or principles contained in Pancasila and the 1945 Constitution (as basic rules). Everything carried out in Indonesia must be adapted to the matters contained in Pancasila and the 1945 Constitution because these two things are the basis for developing the life of the nation and state. Furthermore, everything done in Indonesia must, of course, be based on law, considering that the state of Indonesia is a legal state specialising in implementing reforms in the field of legislation. Because currently, reforming the laws and regulations in Indonesia is necessary to improve this country's legal system.

Legal reform must be carried out because there are many conflicting regulations. In this case, the most crucial aspect of legal reform is harmonising laws and regulations. Harmonisation of direction is required, or the ability to reconcile statutes and rules with other rules that previously overlapped. Minister of State Secretary Pratikno conveyed the government's "criticism" regarding the "regulatory obesity" that hinders investment in Indonesia at the 6th National Conference on Constitutional Law with "Strengthening the Effective Presidential Cabinet" in Jakarta on 2-4 September 2019. The ministry issued regulations that could help investment. 15 Ministries make a potential investment opportunistic. There were 7,621 Ministerial Regulations, 765 Presidential Regulations, (a) Possible overlap; (b) harmonisation and synchronisation costs; (c) No, some institutions carry out monitoring and evaluation.

According to Regulations.go.id-data sources as of March 20, 2020, the number of provisional laws and regulations is 1,687, non-statutory government regulations 180, government regulations 4,533, presidential decrees 2006, BPK Regulation 26, Bank Indonesia Regulation 146, Service Authority Regulations There are 328 finances, 3,722 Ministerial Regulations, 15,960 Regional Regulations, a total of 43,235. To overcome these legal problems and achieve legal harmonisation, the government should pass a law that adopts the legal omnibus concept to cut bureaucracy, roll out the red carpet, and open entry opportunities for foreign investors.

President Joko Widodo first conveyed the formation of the collective rights law in his first speech after being sworn in during his second term as President of the Republic of Indonesia at the General Assembly of the People's Consultative Assembly (MPR) October 20, 2019. President Joko Widodo invited the House of Representatives (DPR) to discuss critical laws, including tax laws, job creation and strengthening small and medium enterprises (MSMEs). So that after the President broadcast it from the beginning and until the legislative process was completed with the Omnibus Law, it turned into a hot conversation. President Joko Widodo interpreted and stated that collaborative law is "a law that reviews several laws at once, including dozens of laws.

President Joko Widodo was then realised through one concrete step in submitting the Draft Law (RUU) on Job Creation to the Chairman of the DPR on February 7, 2020, with Presidential Letter No. R-06/Pres/02/2020 bus National Legislation Program The 2020 Priority Bill (Prolegnas Priority 2020) is used as one of the Priority Bills at the 8th Plenary Session of the Second Session of the 2019-2020 Session Year. The government said this bill to be used to build the Indonesian economy to attract investment. The government drafted this bill to serve as a plan to develop the Indonesian economy to attract investors to invest in Indonesia. The government sees the need for this law to create jobs because of the high unemployment rate in Indonesia. The Job Creation Law consists of 11 groups [3].

According to the government, this is one of the strategies to encourage economic growth by increasing investment through business license reform. The implemented reforms aim to remove investment barriers, namely long bureaucratic chains, overlapping regulations, and 
many rules that are not harmonious, especially in central and regional regulations. Therefore, it is necessary to review the provisions regarding business licenses, investment requirements, employment, micro, small and medium enterprises, including cooperatives, land acquisition, development of economic zones, implementation of government projects, and provisions on state administration the imposition of criminal sanctions. Contained in various regulated laws [4]. The government is also trying to create jobs by encouraging the development of MSMEs and cooperatives as one of the main pillars of the Indonesian economy. Data from the Ministry of Cooperatives and SMEs shows that 62 (sixty-two) and 99 (ninety-nine) per cent of companies in Indonesia are MSMEs and cooperatives with a workforce absorption of 97 (ninety-seven) per cent.

With the enactment of Law Number 11 of 2020 concerning Job Creation (from now on UUCK), the boundaries of the concept of regulation have begun to be developed, not merely statutory regulations. One of them is the introduction of "risk-based regulation" (after this referred to as RBR). In UUCK, simplification of permits is carried out through various mechanisms, including through the RBBR approach to company permits and their monitoring and the integration of multiple tokens into company permits. Based on the risk approach, "operating licenses" are issued in stages, with "approval" only required for high-risk companies, while for medium and low-risk levels, no approval is needed. (see figure 1) [5].

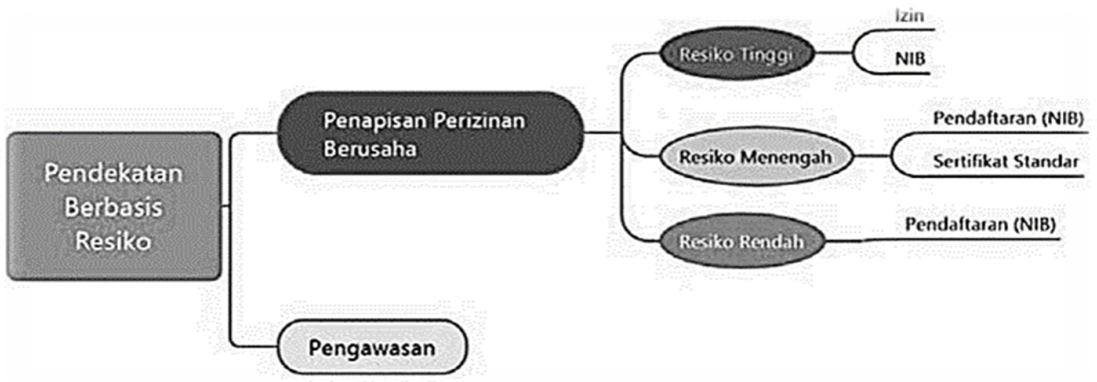

Fig. 1. Risk-Based Approach in UUK

This shows that the business landscape in Indonesia includes mainly SMEs and cooperatives. However, with such a large number of business units, MSMEs and cooperatives are considered unable to direct the community's welfare, especially the lower middle class, towards a higher direction towards the brbroadest possible job opportunities. The government's unique focus on MSMEs and cooperatives is not just to push the economy towards the government's long-term goals. Of course, each new rule is different from the previous one, especially if the rules are precise and a rule conflict arises. Therefore, it is necessary to examine in depth the regulations outlined by lawmakers together with the government to facilitate commercial permits.

\section{Formulation of the Problem}

The OSS application has been equipped with an automatic approval system where this system has standardised several requirements that do not need to be reviewed for submitted documents. As long as the required documents meet administrative requirements, this portal automatically grants permission to commercial actors [6]. 
In the context described by the author in this study, the formulation of the main problem will be explained as follows.

a. How easy is it to get a business license by national and foreign investors in Law No. 11 of 2020 concerning Job Creation?

b. How is the implementation of business permit facilitation for domestic and foreign investors after enacting Law Number 11 of 2020 concerning job creation?

c. How is the impact of Online Single Submission on the ease of investment?

\section{Methodology}

a. Study This normative legal research uses a literature study, namely a legal investigation that presents law as a normative construction system [7]. Therefore, this work uses primary, secondary, and tertiary sources of law. This study tries to examine legal issues by reviewing legal norms contained in the law. and regulations that include monitoring the implementation of state social responsibility for permits that can impact environmental damage in Indonesia[8].

b. This dissertation research focuses on finding out how the influence of a single online presentation on the ease of environmental impact investment in Indonesia from the perspective of environmental law and legal theory and development is carried out under the legal mandate.

c. This study uses an institutional approach and a case approach. A statutory approach is a legislative approach where research is carried out through a survey of laws and regulations related to OSS legal issues carried out by the government on Indonesian industrial companies that have permits through the system.

\section{Results and Discussion}

Investing in different languages has different equivalents. According to English, the word investment has counterparts in other languages, including supporting (Dutch), Investissement (French), Investment (German), Investimento (Italian), Investimento (Portuguese), and Investment (Spain). In the sense of investment, according to the Cambridge dictionary, investment, effort, money, time, and others means investing in something to obtain profits in the form of cash, energy, time or other things used to do different things. Put (money) into any financial plan, stock, property or business venture with the hope of making a profit [8].

According to several participating countries of the International Investment Agreements (IIA), the concept of investment includes investment requirements where the investment is made based on laws and regulations in force in the host country. The purpose of this decision is to prevent violations of the host country's laws, but it is protected by an agreement between the investor and the host country [9].

Investments are generally referred to as investments. This is because the term investment can be equated with investment. These two terms are often found in commercial activities and the language of laws and regulations. However, some argue that the word investment is broader because it can include direct and indirect investments (indirect or portfolio investments). In contrast, investment has a narrower meaning because it has a more direct investment connotation [10]. In 2007 law number 25 concerning investment, it is stated that investment is a form of investment activity carried out by domestic investors or foreign 
investors to conduct business in the territory of the Republic of Indonesia. Elements contained in the investment, among others [11]:

a. All Form of Investment Business what is meant by "all forms of business" is managing a company. Running a business means carrying out an ongoing business activity to obtain profits openly, in a specific action. 12].

b. Investment is divided into two, namely domestic investment and foreign investment [13].

There are no specific regulations in Indonesia that regulate the import of investment law. In general, investment law is a branch of law within a set of investment rules. Within the scope of its application, investment law can take the form of international law, particularly regarding foreign investment or national law [14].

In line with its development, investment law includes civil law and public law. Especially in constitutional law, constitutional law and international law. For example, in the aspect of constitutional law, which is, of course, related to the process of the NRI or local government to designate certain places or regions to carry out investment activities. For example, in the field of state administrative law in relation to investment approvals and legal accountability for state assets or state assets when making investments. So far, the investment rules regulated in Law no. 25 of 2007, the rules for acquisition or investment can be found in various laws and regulations, including:

a. Government Regulation No. 45 of 2008 concerning Guidelines for Providing Incentives and Investment Opportunities in the Regions;

b. 2nd Presidential Regulation No. 76 of 2007 regarding Criteria and Requirements for Closed Commercial Areas.

c. Decision President Number 27 of 2009 concerning One Stop Services in the Investment Sector;

d. 4th Presidential Regulation No. 16 of 2012 concerning the General Investment Plan;

e. Decision 5th President no. 44 of 2016 concerning List of Closed and Open Business Fields with Investment Requirements[15] ;

f. 6 of 2011 regarding Procedures for Implementation, Orientation and Reporting of One Stop Services in the Investment Sector;

g. Regulation of the Chairman of the Investment Coordinating Committee Number 14 of 2015 concerning Policies and Procedures for Granting Licensing following Investment Principles;

h. Regulation of the Chairman of the Plant Coordinating Board Number 15 of 2015 regarding Policies and Procedures for Licensing and Unlicensed Investment;

i. Regulation of the Chairman of the Investment Coordinating Committee Number 16 of 2015 concerning Policies and Procedures for Investment Facility Services;

j. Law of the Head of the Investment Coordinating Board Number 6 of 2016 on Amendments to the Regulation of the Head of BKPM Number 14 of 2015 concerning Guidelines and Procedures for Granting Permits in Principle;

In addition to the various regulations mentioned above. This is important because there is also foreign investment in Indonesia. Therefore, it is also necessary to pay attention to agreements at the international level, especially those that have ratified or signed both bilateral, regional and multilateral investment agreements. Contracts or agreements to consider include:

a. Law Number 32 of 1968 concerning Investment Dispute Settlement Conventions between States and Citizens of Other Countries, otherwise known as ICSID; 
b. UU no. 71994 concerning the ratification of the agreement establishing the World Trade Organization, which also includes deals on trade aspects related to intellectual property rights (TRIPS), trade aspects related to investment actions (TRIM) and general agreements on trade in services. . (GATS);

c. Decision President Number 34 of 1981 concerning Ratification of the Convention concerning the Recognition and Enforcement of Foreign Arbitral Awards;

d. Decision Fourth President Number 31 of 1986 concerning Ratification of the Agreement for the Establishment of a Multilateral Investment Guarantee Agency or known as MIGA;

e. International investment agreements and other international trade cooperation, both bilateral (bilateral investment treaties or BITs) and multilateral (e.g. ASEAN free trade agreements, Asia-Pacific economic cooperation, and ASEAN-China free trade agreements).

In Indonesia, the investment regime is contained in Law no. $25 / 2007$, which only limits the scope of direct investment. As explained in the Elucidation of Article 2 of Law Number 25 of 2007, which stipulates that "Investment in all areas of the territory of the Unitary State of the Republic of Indonesia" is a direct investment and does not include indirect investment or portfolio investment. 25 of 2007 does not recognise asset-based investment (definition of asset base). 25/2007 is based on commercial activities (report based on interpretation). Because the focus is on long-term investment. Long-term direct investment will enable developing countries to benefit more not only in terms of foreign exchange inflows but also in terms of increased production, expansion of knowledge, (a) Foreign direct investment is identical to direct capital ownership; capital is owned directly by investors. In general, FDI is carried out by investors who already have effective voting rights in managing the company. (b) Indirect foreign investment (indirect investment and portfolio investment) Indirect investment is generally a short-term investment that involves transactional activities in the capital or money market.

Due to the differences mentioned above, it is also necessary to know one of the indicators for a country as a benchmark for a conducive investment climate, namely regulation. Systematic regulation in the field of investment will provide legal certainty to investors. In addition, a conducive investment climate will encourage companies to make productive investments, create jobs, and develop their businesses. Therefore, efforts to promote direct investment in Indonesia are a must. Not all developing countries have a favourable investment climate for foreign investors. So far, the investment climate continues to develop in a more positive direction. Therefore, improving the investment climate will remain a critical thought that will always be faced by developing country governments. Community service is the main task of the government. The government is at your service to act as a catalyst to speed up procedures according to regulations. Therefore, the government's performance as a service provider to the community is primarily determined by the services. This service aims to determine the extent to which services are provided to the community so that these services are affordable, fast and efficient both in terms of time and efficient financing.

In its development, post-obligation public services emerged to organise government activities that were group or individual. There is no justification for differential treatment in providing services, which can reduce discrimination in society. Another thing that also needs to be contributed is the management of services whose existence must be improved through openness and simplicity of procedures, transparent and affordable rates, professionalism of equipment in service and the availability of adequate public complaints. As well as the availability of a monitoring system to implement procedures. Concerning investment approval, a service system has now been developed which has the main objective of creating 
friendly services for investment approval. Of course, both at home and abroad, the principle of this system is without limiting the requirements that must be imposed on the concept of a roof service system. Previously, the investment licensing service applied was a single online filing system based on a one-stop service system.

However, this concept shows many changes at the lower level. Investors can certainly experience a process related to requirements, costs and time of expenditure that does not have to be measured or determined by investors. The goal is to create investment approval procedures that can be classified as profitable, fast and straightforward, of course under established public service standards. In addition, it can also be said that investment licensing services at the central and regional levels must comply with existing provisions, procedures and regulations to create a common perception in the requirement of licensing services both on the legal basis of the service, which is given.

The standardisation of public services in granting investment permits achieves a standardised system and service capacity so that domestic and foreign investors can determine the accessibility of services provided by investment providers. From here, the role and role of licensing service institutions are needed, especially in the commitment to implementing investments in the regions. This is to regulate and standardise securities licensing services to achieve legal certainty in administering securities services in the areas so that national and foreign investors can use their capital smoothly and measurably.

In the absence of standardisation in licensing services for investment aspects, of course, it will impact investment applications, which investors generally complain about is the high-cost economy. So far, experts have found it challenging to define the permission. This was stated by Sjachran Basah [17]. His opinion is as valid in the Netherlands as Van Der Pot's Het is uiterst moeilijk voor begrip vergunning even definite te vinden (it isn't easy to define the meaning of authorisation) [18]. Each expert views the object they represent from a different angle. However, the difficulty of providing a definition does not mean that it is not defined but that several additional reports have been found.

Thus, Article 1 (9) confirms that a permit grants legality to a person or business actor/particular activity in the form of a license or a business registration certificate. The meaning of permit and permit is also the same in Article 1, point 8 and number 9 of the Regulation of the Minister of Home Affairs no. The substance has the following characteristics: accessible, limited permits, good permits, expensive permits, soon to expire, long-term permits, personal permits and material permits.

Based on some of the things mentioned above, it can be concluded that permits are unilateral state actions based on laws and regulations applied to specific events under certain requirements and procedures. [19] From this understanding, several elements of licensing arise, namely as follows: the existence of authority, in the form of a default permit, government agencies, particular events, normality and formality, requirements, the deadline for disbursement of licensing fees, licensing, arbitration of complaints and disputes, monitoring of permit implementation, sanctions, rights and obligations.

Indonesia is a developing country today, expecting that foreign capital can encourage growth and improve the economy. Increased investment is a means to make it easier to do business or invest in Indonesia. As Johannesburg explains, the South African Organization for Economic Cooperation and Development (OECD) notes that, from an economic perspective, transparency reduces risk and uncertainty, encourages investment, reduces the chances of bribery and corruption, and helps introduce barriers. And objectivity, tangible and less tangible, help investors deal with less developed roles, alleviates problematic situations with 
current demands between home and host countries, contributes to employment opportunities between companies and institutions that drive growth.

The fundamental problem is that corporate actors in managing their affairs in the form of licensing take a long time, are complicated, and many institutions regulate it - these problems, with the solution of implementing a licensing system that is easy, simple and fast. According to Osborne and Gaebler, bureaucracy must pay attention to teamwork and collaborator control and not be dominated or controlled by superiors. The new paradigm of bureaucracy has the characteristics of directing, deceiving and creating competition in public services. One of the government models in the New Public Management era is the government model proposed by Osborne and Gaebler, which is known as the concept of "reinventing government", namely [20]; (a) Catalytic government, namely the government that focuses on providing guidance rather than public service products. (b) The government belongs to the community, namely the government that empowers the community by serving. (c) A competitive government, namely a government that has injected a competitive spirit in delivering public services. (d) Missionled government, that is, a government that transforms a rule-led organisation into a missionled organisation. (e) Results-oriented government, namely funding results and not inputs. (f) Governments identify their customers. (g) Entrepreneurial government, which is a government that can create income and not only spend it. (h) Anticipatory government, namely government that seeks to prevent the worst from happening. (i) System decentralised governance, i.e. Governance from hierarchy to participatory and teamwork. (j) Market oriented government (mechanism).

Efforts to dismantle the long, lengthy and confusing bureaucracy and improve the quality of public services for investment purposes are essential. For this reason, the focus is on public services, psychiatrists or civil servants who are less close to implementing the concept of excellent service. Excellent service must be an inseparable part of public services, such as transparency, accountability, requirements, participation, equality and balance of rights, taking into account the parity between providers and recipients of public services. A final report for the World Bank dated June 6, 2005, by the National Economic Research Associates (NERA) defines public sector transparency as a requirement for regulators to explain decisions and processes in regulatory agencies and the reasons for the decision. Make the method available to present findings, and the process for government agencies and the justification of the decision-making process should be publicly available. While properties like[21].

In the provincial/district/city government, there are provincial, district/city investment offices and one-stop integrated services (DPMPTSP) Province, (DPMPTSP) Regency/city is a supporting element for the regional head of the provincial government, regency/regional government, which carries out the primary coordination function in the field of investment in the local and district/city governments. The Electronically Integrated Business Licensing (PSE) service is currently present to provide business licensing services that can apply to all institutions, ministries, and local governments throughout Indonesia, which can be done through the One-Stop Integrated Service (PTSP).

Apart from PTSP, the public can access the OSS system online anywhere and anytime. In the eyes of the government and business actors, the presence of this PP on OSS is an effort by the government to simplify the business licensing process and create a licensing service model that has been integrated quickly, cheaply, and provides certainty. Through this OSS system, business licenses can be pocketed by business actors in less than an hour. The basic concepts in electronically integrated licensing services include: 
1. The central government is the President of the Republic of Indonesia who holds the power of the government of the Republic of Indonesia, assisted by the vice president and ministers;

2. The regional government is the administration of government affairs by the provincial government and the regional people's representative council;

3. The regional government is the regional head as an element of regional government organiser who leads the implementation of government affairs which are the authority of the autonomous region;

4. Business Licensing is a registration given to business actors to start and run a business and activity and is provided in the form of approval as outlined in a letter/decision or fulfilment of requirements and commitments;

5. Electronically Integrated Business Licensing or Online Single Submission (OSS) is a business license issued by the OSS institution for and on behalf of the minister, head of the institution, governor, or regent/mayor to business actors through an integrated electronic system;

6. Business actors are individuals or non-individuals who carry out business and activities in specific fields;

7. Registration is the registration of businesses and activities by business actors through OSS;

8. A business license is a license issued by for and on behalf of the minister, head of the institution, governor, or regent/mayor after the business actor registers and to start a business and activity until before commercial or operational implementation by fulfilling the requirements and commitments;

9. A commercial or operational permit is a permit issued by the OSS institution for, and on behalf of the minister, head of the institution, governor, or regent/mayor after the business actor has obtained a business license and to carry out commercial or operational activities by fulfilling the requirements and commitments;

10. Commitment is a statement by a business actor to fulfil the requirements for a business license and commercial or operational license;

11. Institution OSS Manager and Operator (OSS Institution) is a non-ministerial government agency that carries out government affairs in the field of investment coordination;

12. Business Identification Number (NIB) is the identity of the business actor issued by the OSS institution after the business actor registers;

13. Taxpayer Identification Number (NPWP) is a number given to taxpayers as a means of tax administration which is used as personal identification or identity of the taxpayer in exercising his tax rights and obligations;

14. Company Registration Certificate (TDP) is a letter of approval given by the OSS institution to business actors who have registered;

15. Number Importer Identification (API) is identified as an importer;

16. Population Identification Number (NIK) is a resident identity number that is unique or distinctive, singular, and attached to a person who is registered as a resident of Indonesia;

17. Plan for Employment of Foreign Workers (RPTKA) is a plan for the use of foreign workers in certain positions made by employers of foreign workers for a certain period ratified by the minister in charge of government affairs in the workforce sector. or appointed official;

18. Location permit is a permit granted to a business actor to obtain land needed for his business and activity and also applies as a permit to transfer rights and to use the land for his business and activity; 
19. Water Location Permit is a location permit that exists in the laws and regulations in the field of management of coastal areas and small islands;

20. Detailed Spatial Planning (RDTR) is a clear plan for regency/city spatial planning;

21. An environmental permit is a permit granted to a business actor conducting a business and activity for which AMDAL or UKL-UPL is required in the context of environmental protection and management as a prerequisite for obtaining a company and activity permit;

22. Effort Environmental Management and Environmental Monitoring Efforts (UKL-UPL) is the management and monitoring of businesses and activities that do not have a significant impact on the environment that is required for the decision-making process regarding the implementation of companies and activities;

23. Environmental Impact Analysis (AMDAL) is a careful and in-depth study of the significant impact of a planned business and activity on the environment that is required for the decision-making process regarding the implementation of a company and training;

24. Environmental Impact Analysis (ANDAL) is a careful and in-depth study of the significant impacts of a planned business and activity;

25. Environmental Management Plan (RKL) is an effort to handle the impact on the environment caused by the business and activity plan;

26. Environmental Monitoring Plan (RPL) is an effort to monitor environmental components that are affected by the business and activity plan;

27. Building Construction Permit (IMB) is a permit granted by the district/city government to building owners to build new, modify, expand, reduce and maintain buildings following applicable administrative and technical requirements;

28. One-Stop Integrated Service (PTSP) is a service that is integrated into a single process starting from the application stage to the stage of completion of service products through one door;

29. The electronic document is any electronic information created, forwarded, sent, received, or stored in analogue, digital, electromagnetic, optical, or similar forms that can be seen, displayed, and heard through a computer or electronic system, but not limited to sound. , writings, maps, pictures, designs, photographs or the like, letters, signs, numbers, access codes, symbols or perforations that have meaning or meaning or can be understood by people who can understand them; and

30. Sign electronic signature is a signature that consists of electronic information that is attached, associated or related to other electronic communication that is used as a means of verification and authentication.

The central government establishes a policy on administering authority over granting business permits that regulate sectoral power or regional hegemony in the licensing process. It is not held in the law and does not conflict with PP OSS. Business licensing includes providing facilities and ease of doing business. For the central government to provide guidance and supervision of implementing the authority to grant business licenses. The scope of services trying to be integrated electronically include (a) Type, Applicants, and Business License Issuers; (b) Implementation of business licensing; (c) Reform sector business licensing; (d) OSS system; (e) OSS Institution; (f) OSS Funding; (g) Incentives or disincentives for implementing business licensing through OSS; (h) Resolution of problems and barriers to business licensing through OSS; and (i) Penalty; (j) Type Old Model Licensing and Types of Business Licensing (OSS). 
Licensing services have changed from manual, convoluted licensing and take a long time to process. The licensing service has become an easy, transparent and fast system for business actors. All of that is to increase investment and investment. The current licensing service system with electronically integrated business licensing or Online Single Submission (OSS) is a business license issued by the OSS institution for and on behalf of the minister, head of the institution, regent/mayor, or governor to business actors through OSS. OSS is used to administer business permits for business actors with the following characteristics: (a) In the form of individuals and business entities (micro, small, medium and large); (b) Business both individuals and business entities, whether established before the operation of OSS or new ones; (c) Capital business entirely from within the country, or there is a composition of foreign capital.

On the other hand, the Investment Coordinating Board (BKPM) optimises the performance of the Task Force (Satgas) to accelerate efforts to boost investment growth. This task force works to complement the existing OSS licensing system. This task force oversees the commitment of investors who have submitted their application through OSS to be realised immediately, whether OSS work at the centre, ministries, provinces and others. This is because from the previous BKPM data, investment only grew by four per cent throughout 2018 , or it can be down compared to 2017 , which touched 10 per cent.

Electronically integrated business licensing services must be prepared under norms, standards, procedures and criteria for business licensing and investment facilities. Investment facilities are all forms of fiscal and non-fiscal incentives and the ease of investment services under laws and regulations. The government is currently changing perspective on the licensing system with several legal products related to licensing services that are trying to be integrated electronically. A business license in connection with OSS is a license that has been issued by the central PTSP, whose existence is at BKPM for and on behalf of the minister or head of the institution after the business actor has registered and to start the activity and business until before the implementation of the operational or commercial training process with the fulfilment of requirements set out in the commitment.

\section{Conclusion}

The concept of RBR is a new thing in academic discourse in Indonesia. Along with the UUK edition, the idea has a place to simplify business licensing. Applying the RBR concept to the UUK opens public and scientific discourse on regulation, which is not only interpreted by legal norms. However, several things related to the implementation of RBBR in the Constitution deserve criticism. This document presents 4 (four) points of criticism towards the RBR approach in UUCK. The RBR approach in UUCK differs from the widespread practice of RBR because RBR is generally used more in the context of supervision. RBR in UUCK emphasises the selection of business licenses. In addition, the provision of UUK in an omnibus format makes it challenging to identify regulatory objectives.

Risk identification is not possible without clarity of regulatory objectives because it is a derivative of regulatory purposes. Regulatory goals overlap by incorporating changes to various laws in an omnibus format. The task of each sector after the issuance of the law is to identify the purposes of each regulation. The main objectives contained in the Constitution confuse the regulatory goals of each industry. Another criticised point was the lack of detail on volatile and systemic risks in the UUK. The delegation that gave the authority to further regulate volatile and systemic risks in PP even strengthened it. The PP is a legal regulation 
that is difficult to change. Volatile and systemic risks should be classified as separate risks and treated differently. Regarding the potential scope of the law when applying RBR to UUK, it may be weakened by regulations in $\mathrm{PB}$ which require transparency, openness and public participation in risk identification and evaluation.

\section{References}

[1] Yopi Gunawan dan Kristian, Perkembangan Konsep Negara Hukum dan Negara Hukum Pancasila, Bandung: PT. Refika Aditama, 2015, h. 1

[2] Ahmad Redi dan Ibnu Chandra, Omnibus Law Diskursus Pengadopsiannya Ke Dalam Sistem Perundang-Udangan Nasional, Depok, Rajawali Pers, 2020, hlm. V

[3] Wisnu Aryo Dewanto, Problematika Pembentukan RUU Cipta Kerja Dengan Konsep Omnibus Law Pada Klaster Ketenagakerjaan Pasal 89 Angka 45 Tentang Pemberian Pesangon Kepada Yang di PHK, Jurnal Panorama Hukum Volume 5 Nomor. 1 Tahun 2020, hlm. 64

[4] Dalam Naskah Akdemik Rancangan Undang-Undang Cipta Kerja, hlm. 23

[5] Istilah "perizinan berusaha" berbeda dengan "izin". "Perizinan Berusaha" adalah legalitas yang diberikan kepada Pelaku Usaha untuk memulai dan menjalankan usaha dan/atau kegiatannya (Pasal 1 angka 4 UUCK). Sementara "izin" merupakan persetujuan Pemerintah Pusat atau Pemerintah Daerah untuk pelaksanaan kegiatan usaha yang wajib dipenuhi oleh Pelaku Usaha sebelum melaksanakan kegiatan usahanya (Pasal 10 ayat 92) UUCK). Untuk memahami konteks keseluruhan mengenai perizinan berusaha lihat Pasal 6 s.d. 12 UUCK.

[6] https://www.easybiz.id/poin-poin-penting-dalam-proses-pengajuan-izin-usaha-melaluioss/

[7] Mukti Fajar N.D dan Yulianto Achmad, Dualisme Penelitian Hukum Normatif \& Empiris, Yogyakarta: Penerbit Pustaka Pelajar, 2010, hlm 34

[8] Amiruddin, dan H. Zainal Asikin, Pengantar Metode Penelitian Hukum, Jakarta: PT Raja Grafindo Persada, 2003, Hlm. 118.

[9] John Downes dan Jordan Elliot Goodman, Kamus Istilah Keuangan dan Investasi, alih Bahasa oleh Soesanto Budhidharmo (Jakarta: Elex Media Komputendo, 1994), hlm. 300 .

[10] Mahnaz Malik, "Recent Developments in the Definition of Investment in International Investment Agreements," Second Annual Forum of Developing Country Investment Negotiators (Marrakech, Marocco: 3-4 November 2008).

[11] Ida Bagus Rahmadi Supancana, Kerangka Hukum Kebijakan Investasi Langsung di Indonesia, (Jakarta: Ghalia Indonesia, 2005) hlm. 1.

[12] Selanjutnya disebut Undang-Undang No. 25 Tahun 2007. Undang-Undang ini ditandatangani oleh Presiden tanggal 26 April 2007 menggantikan UU No. 1 Tahun 1967 tentang Penanaman Modal Asing dan UU No. 6 Tahun 1968 tentang Penanaman Modal Dalam Negeri. Lihat Erman Rajagukguk, Hukum Investasi di Indonesia (Jakarta: Universitas Al-Azhar Indonesia, 2007), hlm. 41

[13] Pasal 1 angka 7 Undang-Undang Nomor 25 Tahun 2007.

[14] Pasal 1 angka 2 dan angka 3 Undang-Undang No. 25 Tahun 2007.

[15] Tesfaye Abate, Investment Law Teaching Material, Prepared under the sponsorship of the Justice and Legal System Research Institute (2009), hlm. 37-39. 
[16] Peraturan ini sering disebut Investment Negative List karena merupakan pedoman dalam mengidentifikasi bidang-bidang usaha manakah yang terbuka untuk penanaman modal atau yang terbuka dengan persyaratan tertentu.

[17] Mahmul Siregar, Perdagangan Internasional dan Penanaman Modal (Medan: Universitas Sumatera Utara, 2005), hlm. 387.

[18] Sjachran Basah, Pencabutan Izin Salah Satu Sanksi Hukum Administrasi, Makalah pada Penataran Hukum Administrasi dan Lingkungan di Fakultas Hukum Unair, Surabaya, 1995, hlm. 1-2

[19] E. Utrecht, Pengatar dalam Hukum Indonesia, (Jakarta: Ichtiar 1957), hlm. 187.

[20] https://www.hestanto.web.id/unsur-unsur-perizinan/,

[21] Osborne dan Gaebler. 2005.Reinventing Government, Mewirausahakan Birokrasi, PenterjemahAbdul Rasyid.Jakarta: Penerbit PPM, hlm. 38.

[22] Richard \& Anna Naviski, 2005, Regulatory Transparency: International Assesment and Energing Lessons, a final Report for the World Bank, NERA, London, hlm. 25, dikutip dari buku karya Siti Kotijah, Buku Ajar Hukum Perizinan, Yogyakarta: CV. MFA, 2020, hlm. 27. 